\title{
Pulmonary Diffusing Capacity in Lambs during the Early Neonatal Period
}

\author{
JOHN M. BISSONNETTE, ${ }^{(16)}$ WILLA H. DRUMMOND, WALTER K. WICKHAM, AND \\ JAMES Z. CRONAN \\ Department of Obstetrics and Gynecology, School of Medicine, University of Oregon Health Sciences Center, \\ Portland, Oregon, USA
}

\begin{abstract}
Summary
A rebreathing method was used to make 53 measurements of pulmonary diffusing capacity $\left(\mathrm{D}_{\mathrm{Lco}}\right)$ and functional residual capacity $(F R C)$ in 17 newborn lambs during the first 2 days of life. $D_{\text {Lco }}$, FRC, and $D_{\mathrm{Lco}} / \mathrm{FRC}$ all increased in studies made at 24-48 $\mathrm{hr}$ of age compared to those at $2-4 \mathrm{hr}$ of age: $D_{\mathrm{Lco}} 0.86 \pm 0.18$ to 1.52 $\pm 0.09 \mathrm{ml} / \mathrm{min} /$ torr; FRC $37 \pm 10$ to $60 \pm 8 \mathrm{ml}$ and $D_{\mathrm{Lco}} / \mathrm{FRC}$ $2.52 \pm 0.75$ to $2.89 \pm 0.37 \mathrm{ml} / \mathrm{min} /$ torr $/ \mathrm{ml} \times 10^{-2}$. $D_{\text {Lco }}$ measured using $0.005 \% \mathrm{CO}$ in the test gas was not different than that measured using $0.5 \% \mathrm{CO}$.
\end{abstract}

\section{Speculation}

The increase in pulmonary diffusing capacity is in part due to an increase in lung volume, but the significant increase in $D_{\mathrm{Lco}} / \mathbf{F R C}$ demonstrates that other factors such as a change in pulmonary capillary blood volume may also be important. We conclude that there is no evidence for a $\mathrm{CO}$ carrier in the early neonatal period in lambs.

The $\mathrm{D}_{\mathrm{Lco}}$ is an index of the lung's capability for oxygen transport and is dependent upon alveolar volume and pulmonary capillary blood volume. Although $\mathrm{D}_{\mathrm{Lco}}$ has been measured in human neonates $(6,9,12)$, none of these studies have made a systematic examination of the first 2 days of life. The early neonatal period involves the establishment of FRC $(1,7,8)$ and the reabsorption of pulmonary fluid $(2,5,11)$, which may in turn affect the volume of blood in the pulmonary capillary bed. We have measured $D_{\text {Lco }}$ and FRC by a rebreathing method in lambs in lambs at $2-4 \mathrm{hr}$ of age and at $24-48 \mathrm{hr}$ of age in order to evaluate any changes in these parameters.

It has recently been suggested that $\mathrm{CO}$ uptake by the lung is not only simple diffusion but in part involves a facilitated transport mechanism (3). In newborn lambs the facilitated component for $\mathrm{CO}$ was not present at birth but could be found in lambs at 9 days of age. In an effort to explore the possibility of carrier-mediated $\mathrm{CO}$ diffusion, we have made measurements of $\mathrm{D}_{\mathrm{Lco}}$ at both low $(0.005 \%)$ and high $(0.5 \%)$ inspiratory concentrations of $\mathrm{CO}$. We reasoned that if there is any carrier mechanism, $D_{\text {Lco }}$ at the high $\mathrm{CO}$ levels would be less than that measured at the low level.

\section{MATERIALS AND METHODS}

The studies were performed in lambs from mixed Western ewes with known breeding dates delivered at 135-144 days of gestation (term is $147-150$ days). Under spinal anesthesia (tetracaine hydrochloride $30-40 \mathrm{mg}$ ) cesarean section was performed and the lambs were removed, dried, and placed under a warming lamp. No recuscitative measures were carried out and the lambs in these studies breathed spontaneously with no signs of respiratory distress. Prior to measuring the diffusing capacity, the lambs were lightly anesthetized with phenobarbital (30-50 mg/ $\mathrm{kg}$ iv) and when quiet they were intubated. Lambs in which repeated studies were made were bottle fed.

$D_{\text {Lco }}$ was measured by the rebreathing method (10) with slight modifications for small animals. The volume of the rebreathing system was $400 \mathrm{ml}$ and the lambs were ventilated from a $60-\mathrm{ml}$ syringe. The rebreathing circuit was made up of 3/16-inch ID plastic tubing (Tygon tubing, Norton Plastics and Synthetics Division, Akron, $\mathrm{OH}$ ) which connected the endotracheal tube and ventilation syringe to a double headed pump (model no. W21R031, Cole Palmer Instrument Company, Chicago, IL) where the gas sample was split and run through a helium analyzer (Warren E. Collins Inc., Braintree, MA) and carbon monoxide analyzer (model no. 865 infrared analyzer, Beckman Instruments Inc., Fullerton, CA) in parallel. The output of both analyzers was continuously recorded (model B44 polygraph, Argonaut Associates Inc., Beaverton, OR) at a paper speed of $1.3 \mathrm{~cm} / \mathrm{sec}$. The entire rebreathing circuit was equilibrated with gas made up of either 0.005 or $0.5 \% \mathrm{CO}, 8.0 \%$ helium, $20.9 \%$ oxygen, and balance nitrogen (Airco Industrial Gases, Vancouver, WA). The circuit was then attached to the endotracheal tube at the end of expiration and the lamb rapidly rebreathed at $40-50$ breaths/min with a tidal volume of $60 \mathrm{ml}$ for $30-45 \mathrm{sec}$.

$D_{\text {Lco }}$ and FRC were calculated from the recorded changes in $\mathrm{CO}$ and helium concentrations (Fig. 1) as follows

$$
\mathrm{D}_{\mathrm{Lco}}=\left(0.693 / \mathrm{t}_{1 / 2}\right) \times \mathrm{V}_{\mathrm{S}} / \mathrm{BP}-47
$$

where $\mathrm{D}_{\mathrm{Lco}}=$ lung diffusing capacity in milliliters per min per torr STPD; $\mathrm{t}_{1 / 2}=$ time in minutes for $\left[\mathrm{CO}\right.$ ] to fall by $50 \% ; \mathrm{V}_{\mathrm{S}}=$ volume of the entire rebreathing system (rebreathing circuit plus lung volume) in milliliters STPD; $\mathrm{BP}=$ barometric pressure in torrs.

The half-time for $\mathrm{CO}$ was calculated by plotting the drop in $\mathrm{CO}$ concentration, after the initial fall due to dilution in the lung volume, on semilog paper $v s$. time. The volume of the rebreathing system was calculated from

$$
\mathrm{V}_{\mathrm{S}}=\mathrm{Vc} \times 8.0 /[\mathrm{He}]
$$

where $\mathrm{Vc}=$ the volume of the rebreathing circuit $(400 \mathrm{ml})$ and $[\mathrm{He}]=$ the helium concentration measured after dilution into the lung volume. FRC was obtained from $\mathrm{V}_{\mathrm{S}}-\mathrm{Vc}$, and is in milliliters STPD. After each measurement the rebreathing circuit was equilibrated with room air and then reconnected to the endotracheal tube. The lamb was then ventilated for $30-45 \mathrm{sec}$ exactly as in the measurement of $\mathrm{D}_{\mathrm{Lco}}$. The equilibrium value of $\mathrm{CO}$ in this rebreathing with air was used as the back pressure level for pulmonary blood $\mathrm{CO}$ and subtracted from the alveolar $\mathrm{CO}$ obtained during the initial measurement. The lambs were always studied with $0.005 \% \mathrm{CO}$ first and this was followed with the $0.5 \% \mathrm{CO}$ study in an effort to keep blood $\mathrm{P}_{\text {co }}$ low. The $\mathrm{CO}$ analyzer had a built-in linearizer in the $0.5 \% \mathrm{CO}$ range and we verified that the output was linear in this range of $\mathrm{CO}$ by injecting known concentrations of $\mathrm{CO}$ into the analyzer. In preliminary studies we performed four consecutive measurements, using the same CO con- 
centration, within a $1-\mathrm{hr}$ period on the same animal. The SD was $6-7.5 \%$ of the mean value in these repeated measurements.

\section{RESULTS}

The change in concentration of $\mathrm{CO}$ and $\mathrm{He}$ during a rebreathing experiment are shown in Figure 1, right panel. After the initial dilution into lung volume, the uptake of $\mathrm{CO}$ follows a single exponential as seen in Figure 1, left panel. The birth weight and gestational age at birth of the lambs, the postnatal age at the time $\mathrm{D}_{\mathrm{Lco}}$ was measured, the $\mathrm{CO}$ in the test gas mixture, FRC, $\mathrm{t}_{1 / 2}$, and $\mathrm{D}_{\text {Lco }} / \mathrm{FRC}$ are given in Table 1.

In order to compare lambs over the early neonatal period we have grouped the studies made at $2-4 \mathrm{hr}$ of age $v s$. those made at $24-48 \mathrm{hr}$ of age. In this grouping we took the average $\mathrm{D}_{\mathrm{Lco}}$ of the measurements made with different $\mathrm{CO}$ concentrations in the test gas mixture. We believe this is justified since there appears to be little difference between measurements made with $0.005 \% \mathrm{CO}$ compared to those with $0.5 \% \mathrm{CO}$ (see below). $\mathrm{D}_{\mathrm{Lco}}$ at $24-48 \mathrm{hr}$ was $1.52 \pm 0.09 \mathrm{ml} / \mathrm{min} /$ torr (mean $\pm \mathrm{SEM}, n=9$ ), which is significantly greater than the value at $2-4 \mathrm{hr}$ of age; $0.86 \pm 0.18$ $(n=12), P<0.01, t$-test for unpaired samples. If we include only the five lambs who had serial studies, $D_{\text {Lco }}$ at $24-26 \mathrm{hr}$ is $1.61 \pm$ 0.09 compared to $0.98 \pm 0.06$ ( $P<0.01, t$-test for paired samples). There was an increase in FRC from $37 \pm 10$ to $60 \pm 8$ but the difference is not significant. Since $\mathrm{D}_{\mathrm{Lco}}$ is in part dependent on lung volume (9), we have compared $\mathrm{D}_{\mathrm{Lco}} / \mathrm{FRC}$ in the two age groupings of these lambs. At $2-4 \mathrm{hr}$ of age, $\mathrm{D}_{\mathrm{Lco}} / \mathrm{FRC}(2.52 \pm$ $\left.0.75 \times 10^{-2}\right)$ is less than at $24-48 \mathrm{hr}\left(2.89 \pm 0.37 \times 10^{-2}\right), P<0.05$ $>0.025$. Thus, irrespective of any change in lung volume, the diffusing capacity in the newborn lamb lung increases in the early neonatal period.

The effect of varying the concentration of $\mathrm{CO}$ at which diffusing capacity was measured was examined in the lambs at $2-4 \mathrm{hr}$ and $24-48 \mathrm{hr}$ of age. In the former animals $\mathrm{D}_{\mathrm{Lco}} / \mathrm{FRC}$ measured with $0.005 \% \mathrm{CO}$ was greater than that measured using $0.5 \% \mathrm{CO}$ in the test gas, $2.56 \pm 0.25 \times 10^{-2} \mathrm{ml} / \mathrm{min} /$ torr $/ \mathrm{ml}$ vs. $2.33 \pm 0.21(n=$ 15). The difference is significant $P<0.05>0.025$ using the $t$-test for paired samples. However, in the lambs tested at $24-48 \mathrm{hr}$ of age, no difference could be demonstrated: $0.005 \%=3.01 \pm 0.45$ $\times 10^{-2}$ vs. $0.5 \%=2.82 \pm 0.32 \times 10^{-2}(P>0.05)$. We conclude that in the first 2 days of life no evidence for the partial saturation of a $\mathrm{CO}$ carrier in the lung can be shown.

\section{DISCUSSION}

The values obtained for $D_{\text {Lco }}$ (Table 1) are similar to those reported by Burns et al. (3) in nine newborn lambs (1.46 \pm 0.24 $\mathrm{ml} / \mathrm{min} /$ torr) using the same rebreathing method which we have employed. Our average value at $24-48 \mathrm{hr}$ of age $1.52 \pm 0.09$ ) falls within the ranges reported in human newborns at this age $(6,9$, 12). These latter studies were all made using a steady state $C O$ uptake technique (4).

The most interesting result of this study is the imcrease in pulmonary diffusing capacity which takes place in the first day of life. Although we observed a $77 \%$ increase in the absolute value of $D_{\text {L.co }}$ the increase in FRC contributed to this change. Nevertheless, $D_{\text {Lco }} /$ FRC increased by $15 \%$ from $2-4 \mathrm{hr}$ of age as compared to measurements made in lambs $24-48 \mathrm{hr}$ of age. In an attempt to eliminate the contribution of lung volume to the increase in $\mathrm{D}_{\mathrm{Lco}}$ we have divided $D_{\text {Lco }}$ by FRC. This approach is not entirely justified as it would seem to overemphasize the effects of an increase in FRC. The relationship between $D_{\text {Lco }}$ and FRC in our studies is $\mathrm{D}_{\mathrm{Lco}}$ (milliliters per min per torr) $=0.493+0.0135 \times$ FRC $(\mathrm{ml})$. This equation is obtained from all 53 measurements in Table 1 and the relationship is significant, $r=0.63, P<0.01$. It can be seen from the above relationship that our observed increase in FRC ( 37 to $60 \mathrm{ml}$ ) at $24-48 \mathrm{hr}$, should produce only a $31 \%$ increase in $\mathrm{D}_{\mathrm{Lco}}$. Since the actual increase in $\mathrm{D}_{\mathrm{Lco}}(77 \%)$ is much greater we conclude that other factors such as pulmonary capillary blood volume must also be involved.

The increase in FRC which we have observed in newborn lambs at $24 \mathrm{hr}$ of age compared to $2 \mathrm{hr}$ seems to be at variance with studies in the human $(1,7,8)$. However, the earlier human studies used a plethysmographic technique which measures total thoracic gas volume not FRC. In the study (8) in which helium rebreathing, similar to the method we have used in lambs was employed, only one measurement in each infant was made in the first day of life. This measurement made at about $6-8 \mathrm{hr}$ of age was similar to the determination at 5-6 days. Thus, a strict comparison cannot be made. Inspection of our results in lambs (Table 1) shows that the increase in FRC may have occurred at $4-10 \mathrm{hr}$ of age. However, because most of our studies were carried out either at $2 \mathrm{hr}$ or at 24 hr of age, we cannot state how early in the neonatal period the increase in FRC comes about. The existence of a species difference is also a possible explanation for the inconsistency in the FRC changes.
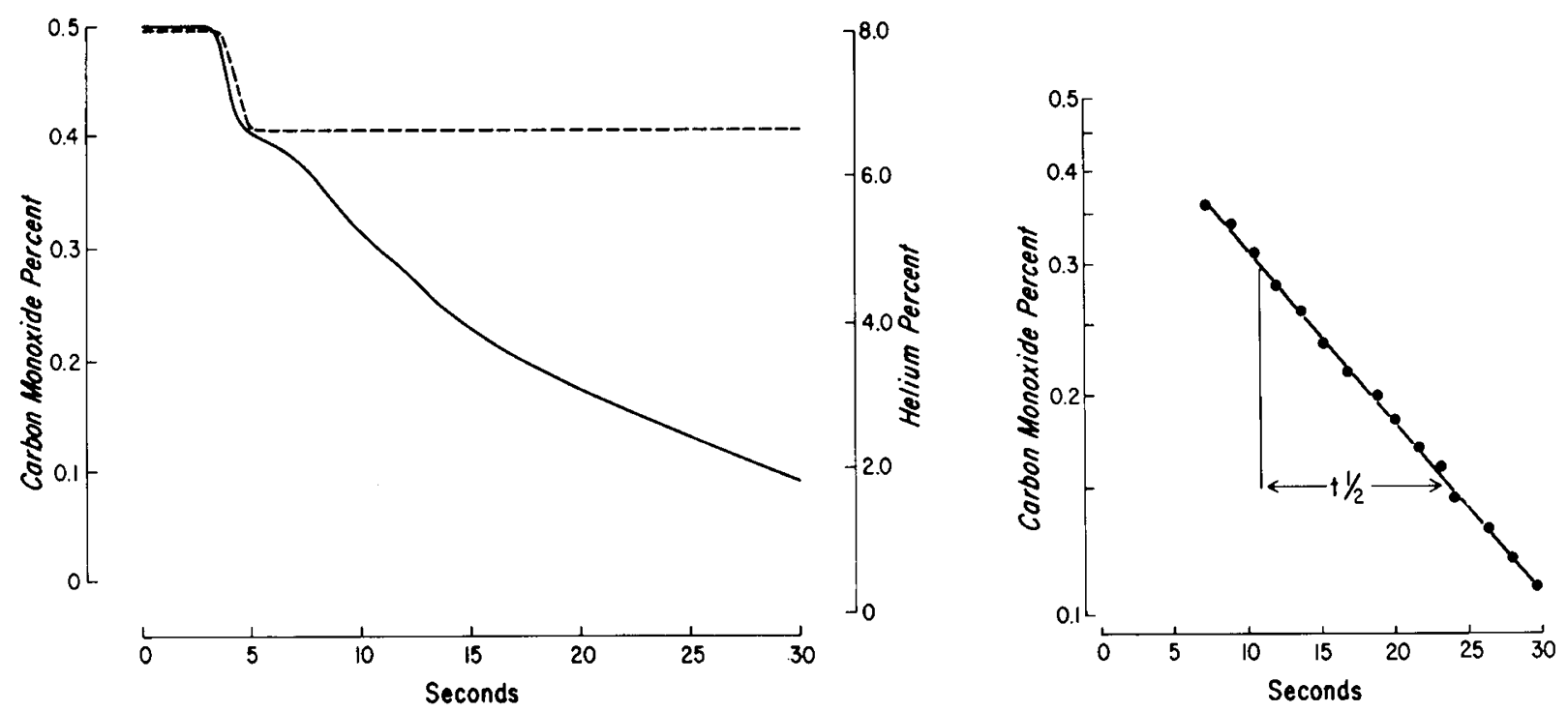

Fig. 1. Right: redrawn from a record showing change in $\mathrm{CO}$ concentration $(-)$ and helium concentration $(---)$ after initiation of rebreathing. Record has not been corrected for instrument response time. Left: example of calculation of half-time for $\mathrm{CO}$ uptake. Data points taken from the record on the right and $\mathrm{CO}$ concentration plotted on a log scale against time in seconds. 
Table 1. Pulmonary diffusing capacities in neonatal lambs ${ }^{1}$

\begin{tabular}{|c|c|c|c|c|c|c|c|}
\hline $\begin{array}{l}\text { Birth wt } \\
(\mathrm{g})\end{array}$ & $\begin{array}{c}\text { Gestational } \\
\text { age } \\
\text { (days } \\
\end{array}$ & $\begin{array}{c}\text { Postnatal Age } \\
(\mathrm{hr})\end{array}$ & $\begin{array}{l}\mathrm{CO} \\
(\%)\end{array}$ & $\begin{array}{c}\text { FRC } \\
(\mathrm{ml} \mathrm{STPD}) \\
\end{array}$ & $\begin{array}{c}\mathrm{t}_{1 / 2} \\
(\mathrm{sec}) \\
\end{array}$ & $\begin{array}{c}D_{\text {Lco }} \\
(\mathrm{ml} / \mathrm{min} / \text { torr }) \\
\end{array}$ & $\begin{array}{c}\mathrm{D}_{\mathrm{Lco}} / \mathrm{FRC} \\
\left(\mathrm{ml} / \mathrm{min} / \text { torr } / \mathrm{ml} \times 10^{2}\right)\end{array}$ \\
\hline \multirow[t]{2}{*}{4147} & \multirow[t]{2}{*}{140} & 2 & 0.005 & 30 & 26.5 & 0.69 & 2.28 \\
\hline & & 2 & 0.5 & 31 & 34.2 & 0.60 & 1.93 \\
\hline \multirow[t]{4}{*}{3900} & \multirow[t]{4}{*}{140} & 2 & 0.005 & 44 & 27.9 & 0.68 & 1.54 \\
\hline & & 2 & 0.05 & 45 & 27.8 & 0.67 & 1.48 \\
\hline & & 4 & 0.005 & 46 & 16.9 & 1.14 & 2.50 \\
\hline & & 4 & 0.5 & 44 & 17.0 & 1.12 & 2.53 \\
\hline \multirow[t]{2}{*}{3006} & \multirow[t]{2}{*}{139} & 2 & 0.005 & 27 & 33.3 & 0.54 & 2.02 \\
\hline & & 2 & 0.5 & 34 & 24.6 & 0.71 & 2.07 \\
\hline \multirow[t]{3}{*}{2400} & \multirow[t]{3}{*}{135} & 48 & 0.005 & 33 & 12.8 & 1.35 & 4.15 \\
\hline & & 48 & 0.5 & 38 & 18.5 & 0.95 & 2.53 \\
\hline & & 48 & 0.5 & 37 & 17.2 & 1.02 & 2.75 \\
\hline \multirow[t]{2}{*}{2100} & \multirow[t]{2}{*}{144} & 30 & 0.005 & 31 & 14.5 & 1.27 & 4.14 \\
\hline & & 30 & 0.5 & 29 & 14.3 & 1.28 & 4.40 \\
\hline \multirow[t]{2}{*}{2400} & \multirow[t]{2}{*}{144} & 30 & 0.005 & 29 & 12.0 & 1.62 & 5.65 \\
\hline & & 30 & 0.5 & 31 & 12.7 & 1.40 & 4.49 \\
\hline \multirow[t]{3}{*}{3100} & \multirow[t]{3}{*}{139} & 2 & 0.005 & 27 & 16.4 & 1.10 & 4.15 \\
\hline & & 2 & 0.5 & 32 & 15.7 & 1.17 & 3.65 \\
\hline & & 4 & 0.005 & 57 & 27.2 & 0.73 & 1.27 \\
\hline \multirow[t]{4}{*}{3000} & \multirow[t]{4}{*}{139} & 2 & 0.005 & 56 & 21.0 & 0.89 & 1.58 \\
\hline & & 2 & 0.5 & 58 & 20.1 & 1.00 & 1.72 \\
\hline & & 4 & 0.005 & 58 & 30.8 & 0.65 & 1.11 \\
\hline & & 4 & 0.5 & 58 & 23.5 & 0.81 & 1.39 \\
\hline \multirow[t]{4}{*}{2480} & \multirow[t]{4}{*}{135} & 2 & 0.015 & 40 & 28.7 & 0.71 & 1.79 \\
\hline & & 2 & 0.015 & 42 & 25.0 & 0.82 & 1.94 \\
\hline & & 2.5 & 0.1 & 34 & 25.0 & 0.80 & 2.34 \\
\hline & & 2.5 & 0.1 & 37 & 26.5 & 0.74 & 2.02 \\
\hline 3500 & 142 & 10 & 0.005 & 53 & 11.5 & 1.72 & 3.23 \\
\hline & & 10 & 0.5 & 57 & 11.3 & 1.76 & 3.08 \\
\hline 4200 & 147 & 48 & 0.015 & 53 & 9.6 & 1.63 & 3.10 \\
\hline & & 48 & 0.1 & 62 & 9.6 & 1.80 & 2.93 \\
\hline 2115 & 143 & 2.8 & 0.005 & 23 & 31.3 & 0.72 & 3.13 \\
\hline & & 2.8 & 0.5 & 31 & 38.3 & 0.60 & 1.94 \\
\hline 2978 & 143 & 2 & 0.005 & 27 & 29.1 & 0.79 & 2.93 \\
\hline & & 2 & 0.5 & 27 & 34.8 & 0.66 & 2.44 \\
\hline & & 2 & 0.5 & 31 & 26.9 & 0.86 & 2.77 \\
\hline & & 24 & 0.005 & 74 & 16.3 & 1.56 & 2.11 \\
\hline & & 24 & 0.5 & 90 & 16.6 & 1.60 & 1.78 \\
\hline 3824 & 142 & 2 & 0.005 & 23 & 21.3 & 1.06 & 4.61 \\
\hline & & 2 & 0.5 & 31 & 18.2 & 1.27 & 4.10 \\
\hline & & 24 & 0.005 & 90 & 16.8 & 1.59 & 1.76 \\
\hline & & 24 & 0.5 & 79 & 13.0 & 2.00 & 2.53 \\
\hline 2811 & 142 & 2.6 & 0.005 & 23 & 29.1 & 0.78 & 3.39 \\
\hline & & 2.6 & 0.5 & 31 & 20.8 & 1.11 & 3.58 \\
\hline & & 24 & 0.005 & 74 & 16.8 & 1.53 & 2.07 \\
\hline & & 24 & 0.5 & 64 & 15.9 & 1.58 & 2.47 \\
\hline 3000 & 140 & 3.3 & 0.005 & 31 & 26.3 & 0.88 & 2.84 \\
\hline & & 3.3 & 0.5 & 49 & 31.2 & 0.78 & 1.59 \\
\hline & & 26 & 0.005 & 59 & 22.1 & 1.12 & 1.90 \\
\hline & & 26 & 0.5 & 64 & 20.7 & 1.22 & 1.91 \\
\hline 3500 & 140 & 3.7 & 0.005 & 54 & 21.2 & 1.16 & 2.15 \\
\hline & & 3.7 & 0.5 & 49 & 20.1 & 1.21 & 2.47 \\
\hline & & 26 & 0.005 & 84 & 14.2 & 1.87 & 2.23 \\
\hline & & 26 & 0.5 & 90 & 13.3 & 2.01 & 2.23 \\
\hline
\end{tabular}

${ }^{1} \mathrm{CO}(\%)$ : concentration of $\mathrm{CO}$ in the rebreathing gas mixture; FRC: functional residual capacity; $\mathrm{t} 1 / 2$, time for $\mathrm{CO}$ concentration to fall by $50 \%$; $\mathrm{D}_{\mathrm{Lco}}$ : pulmonary diffusing capacity; $\mathrm{D}_{\mathrm{Lco}} / \mathrm{FRC}$ : pulmonary diffusing capacity normalized with respect to FRC. 
Burns et al. (3) have presented two arguments in support of the hypothesis that carbon monoxide uptake in the lamb lung is in part carrier mediated. They have shown in lambs at 9 days of age that the administration of 2-diethylaminoethyl-2,2-diphenylvalerate-Hcl (SKF-525A) causes a $45 \%$ drop in $\mathrm{D}_{\mathrm{Lco}}$. This compound, SKF-525A, binds to cytochrome P-450, the proposed carrier for $\mathrm{CO}$ and $\mathrm{O}_{2}$ in the lung. In contrast, SKF-525A showed no effect on $\mathrm{D}_{\mathrm{Lco}}$ in newborn lambs (the exact ages are not given). In addition, these authors have shown that $D_{\text {Lco }}$ measured with $0.0065 \% \mathrm{CO}$ in the test gas is the same as that measured with $0.06 \% \mathrm{CO}$ in newborn lambs. Unfortunately, the studies aimed at demonstrating saturation of a $\mathrm{CO}$ carrier were not performed in lambs at age 9 days (3).

We have chosen to measure $\mathrm{D}_{\mathrm{Lco}}$ at two different $\mathrm{CO}$ concentrations in the test gas in an effort to evaluate any saturation of a $\mathrm{CO}$ carrier in newborn lambs. In the lambs studied at $2-4 \mathrm{hr}$ of age we found that $\mathrm{D}_{\mathrm{Lco}} / \mathrm{FRC}$ measured with $0.005 \% \mathrm{CO}$ was $10 \%$ greater than that measured using $0.5 \% \mathrm{CO}$. While this difference is significant using a paired analysis, the studies at $24-48 \mathrm{hr}$ of age show no difference in $\mathrm{D}_{\mathrm{Lco}}$ at the two $\mathrm{CO}$ concentrations. We conclude that in the first two days of life there is no evidence for partial saturation of a carbon monoxide carrier in the lung.

\section{REFERENCES AND NOTES}

1. Auld, P. A. M., Nelson, N. M., Cherry, R. B., Rudolph, A. J. and Smith C. A.: Measurement of thoracic gas volume in the newborn infant. J. Clin. Invest., 42: $476(1963)$

2. Avery, M. E., and Cook, C. D.: Volume-pressure relationships of lungs and thorax in fetal, newborn and adult goats. J. Appl. Physiol. 16: 1034 (1961).
3. Burns, B., Gurtner, G. H., Peavy, H., and Cha, Y. N.: A specific carrier for oxygen and carbon monoxide in the lung. In: Lung Metabolism, pp. 159-184 (Academic Press, Inc., New York, 1975).

4. Filley, G. F., MacIntosh, D. J., and Wright, G. W.: Carbon monoxide uptake and pulmonary diffusing capacity in normal subjects at rest and during exercise. J. Clin. Invest., 33: 530 (1954).

5. Humphreys, P. W., Normand, I. C. S., Reynolds, E. O. R., and Strang, L. B.: Pulmonary lymph flow and the uptake of liquid from the lungs of the lamb at the start of breathing. J. Physiol. (Lond.), 193: I (1967).

6. Koch, G.: Alveolar ventilation, diffusing capacity and the $\mathrm{A}-\mathrm{a} \mathrm{P}_{\mathrm{o} 2}$ difference in the newborn infant. Resp. Physiol., 4: 168 (1968).

7. Klaus, M., Tooley, W. H., Weaver, K. H., and Clements, J. A.: Lung volume in the newborn infant. Pediatrics, 30: 111 (1962).

8. Krauss, A. N., and Auld, P. A. M.: Measurement of functional residual capacity in distressed neonates by helium rebreathing. J. Pediat., 77: 228 (1970).

9. Krauss, A. N., Klain, D. B., and Auld, P. A. M.: Carbon monoxide diffusing capacity in newborn infants. Pediat. Res., 10: 771 (1976).

10. Lewis, B. N., Lin, T. H., Noe, F. E., and Hayford-Welsing, L. J.: The measurement of pulmonary diffusing capacity for carbon monoxide by a rebreathing method. J. Clin. Invest., 38: 2073 (1959).

11. Orzalesic, M. M., Motoyama, E. K., Jacobson, H. N., Kikkawa, Y., Reynolds, E. O. R., and Cook, C. D.: The development of the lungs of lambs. Pediatrics, 35: 373 (1965).

12. Stahlman, M. T.: Pulmonary ventilation and diffusion in the human newborn infant. J. Clin. Invest., 36: 1018 (1957).

13. The present address of Dr. W. H. Drummond is Division of Cardiology, Department of Pediatrics. University of California Medical Center, San Francisco, CA 94143.

14. Dr. J. M. Bissonnette is the recipient of Research Career Development Award K04 HD-00139 from USPHS.

15. This research was supported by Grants HL-17150 and HD-10034 from USPHS

16. Requests for reprints should be addressed to: John M. Bissonnette, M. D Associate Professor, Department of Obstetrics \& Gynecology, University of Oregon Health Sciences Center, 3181 S. W. Sam Jackson Park Road, Portland, OR 97201 (USA).

17. Received for publication July 20, 1977 ,

18. Accepted for publication December 21, 1977 